\title{
The Effects of Motivation, Language Anxiety, and Test Anxiety on English Proficiency of Japanese Junior High School Students
}

\author{
Rie KOIZUMI \\ Doctoral Course, University of Tsukuba
}

\section{Introduction}

The relationships between second language (L2) learning and learners' affective factors have been extensively examined (see Gardner \& MacIntyre, 1993), especially in studies done on motivation, attitudes, and anxiety. Japan is certainly no exception to this, and recently many investigators have turned to the roles of motivation (e.g., Kimura, Nakata, \& Okumura, 2001; Sawaki, 1997; Tachibana, Matsukawa, \& Zhong, 1996; Teweles, 1996; Yashima, 2000; Yukina, 2000) and anxiety (Cornwell \& McKay, 2000; Katanoda, 1995; Matsuda \& Gobel, 2001; Yukina, 2000). The present research focuses on motivation and anxiety in relation to L2 proficiency.

Motivation refers to "the extent to which the individual works or strives to learn the language because of a desire to do so and the satisfaction experienced in this activity" (Gardner, 1985, p. 10). It can be subdivided into four factors: "a goal, effortful behaviour, a desire to attain the goal, and favourable attitudes toward the activity" (Gardner, p. 50).

In L2 learning, motivation has been considered an influential factor (Gardner, Tremblay, \& Masgoret, 1997). Many studies (e.g., Gardner et al., 1997; Tremblay \& Gardner, 1995; Yamashiro \& McLaughlin, 2001) have consistently demonstrated that motivation has a direct influence on $\mathrm{L} 2$ achievement and proficiency. In contrast, Berwick and Ross (1989) have found that motivation is only weakly associated with proficiency when the target learners are first-year Japanese university students. They go on to explain that the students tend to lose their motivation to study after passing the entrance exams, therefore leading to the partial relationship between motivation and proficiency.

Anxiety is defined as "the subjective feeling of tension, apprehension, nervousness, and worry associated with an arousal of the autonomic nervous system" (Horwitz, Horwitz, \& Cope, 1986, p. 125). It is "a complex, multifaceted construct" (Phillips, 1992, p. 14), related to cognitive processing (Eysenck \& Calvo, 1992). In relation to L2 learning, anxiety falls into the category of language anxiety and test anxiety. While Horwitz et al. include test anxiety in the broader category of language anxiety, MacIntyre and Gardner (1989) and Aida (1994) argue that test anxiety is a specific, relatively unique type of apprehension, different from language anxiety. Since MacIntyre and Gardner's and Aida's claims are supported empirically, language anxiety is treated as being distinct from test anxiety in this study. 
Along with motivation, anxiety has been viewed as an important element in affecting achievement and proficiency (e.g., Cornwell \& McKay, 2000; Zeidner, 1998). It has been shown that the relationship between anxiety and performance is not linear (Ellis, 1994) and that anxiety can have both facilitating (i.e., positive) and debilitating (i.e., negative) effects on performance (Alpert \& Harber, 1960). However, many studies (e.g., Horwitz, 2001; Phillips, 1992; Yamashiro \& McLaughlin, 2001) suggest that there is a negative relationship between language anxiety and L2 learning. On the other hand, Sparks and Ganschow (1995) take another view, claiming that language anxiety is not a cause, but rather a result of learning. In terms of test anxiety, some studies reported that the performance from students with high test anxiety is impeded (e.g., Zeidner, 1998; Araki, 1991), while others provided evidence that test anxiety has no relationship with language achievement (e.g., Horwitz, 1986; MacIntyre \& Gardner, 1989).

As Ellis (1994) states, most of the early studies utilized correlational designs in investigating the relationships between motivation, anxiety, and language learning. Recently, structural equation modeling (SEM; see Kunnan, 1998) has been used in order to examine the causal relationships in various models and to see how well the model fits the data. ${ }^{1}$ Yamashiro and McLaughlin (2001) performed a study that utilized SEM and examined the direct effect of motivation and anxiety on L2 learning. ${ }^{2}$ They constructed a model of the relationships between attitudes, motivation, language anxiety, ${ }^{3}$ and L2 proficiency. In their model, attitudes are highly correlated with motivation, and the latter has a considerable positive influence on proficiency, along with a very slight one on language anxiety. In addition, language anxiety itself has a small negative effect on proficiency. Since the participants in this particular study were Japanese university students, it seems that further investigations are needed involving other types of learners.

The current study attempts to partially replicate Yamashiro and McLaughlin (2001) with Japanese junior high school students. The research question is to investigate to what extent motivation, language anxiety, and test anxiety influence L2 proficiency of Japanese junior high school students. In order to focus on the direct causes of L2 proficiency, the present study does not deal with attitudes. This research is important in terms of examining the roles that anxiety plays in junior high school students because "the relationship between anxiety and achievement in younger learners remains relatively unexplored" (Horwitz, 2001, p. 115). Two other significant points lie with the inclusion of test anxiety in the investigation and of a speaking proficiency score as a component of L2 proficiency, both of which were not included in Yamashiro and McLaughlin. 


\subsection{Participants}

\section{Method}

The participants in this research included 129 Japanese learners of English (64 boys and 65 girls) from the ages of 13 to 14. They were in the second year at two different public junior high schools, located in rural areas of the Kanto district of Japan. They had studied English for at least one year in school. Although there were originally 180 students, 51 were excluded because not all of the questionnaire items or tests were answered properly.

\subsection{Materials}

The questionnaire and the two additional tests (the STEP Test and a speaking test developed by the author) were utilized for this study. The questionnaire was intended to examine affective reactions of students, while the STEP Test and the speaking test were considered indicative of English proficiency. The fifth grade STEP Test, which was officially conducted in January of 1997, included 50 multiple-choice items that assessed knowledge of vocabulary and grammar (30\% of the whole test) and reading $(20 \%)$, writing (10\%), and listening (40\%) ability. The questionnaire and the speaking test were pilot-tested and revised using the feedback given from four English-major graduate students, as well as two first-year and two third-year junior high school students. The materials were administered in June and July of 2000.

\subsubsection{Questionnaire}

The 64-item questionnaire was designed primarily to measure three affective variables: motivation, language anxiety, and test anxiety (see Appendix 1). Table 1 summarizes the categories and types of items found in the questionnaire. Item selection was made based on its relevance to Japanese junior high school students. Motivation in this study included items regarding attitudes toward learning English, while language anxiety contained items related to communication apprehension. Items from three existing questionnaires were selected to reflect multicomponential aspects of test anxiety. In addition, some items were created based on interviews done with those

Table 1 Organization of the Questionnaire

\begin{tabular}{llr}
\hline \multicolumn{1}{c}{ Categories } & \multicolumn{1}{c}{ Sources } & Item $n$ \\
\hline Motivation & Made by the author & 7 \\
\hline Language anxiety & Foreign Language Classroom Anxiety Scale (Horwitz et al, 1986) & 7 \\
\hline Test anxiety & Test Anxiety Scale for Children (Araki et al., 1979) & 12 \\
& Test Influence Inventory (Fujii, 1993) & 20 \\
& Achievement Anxiety Scale (Alpert \& Harper, 1960)* & 10 \\
& Made by the author & 4 \\
\hline Lie scale & Test Anxiety Scale for Children (Araki et al., 1979) & 4 \\
\hline
\end{tabular}

Note. ${ }^{*}=$ items translated by the author; Item $n=$ The number of items. 
students who are motivated or who tend to become rather anxious. Additionally, four lie scale items (Araki, Sato, \& Nei, 1979) were added to check the validity of the answers. The response format was a 5-point Likert scale ranging from strong disagreement (1) to strong agreement (5). Some items were negatively worded. After the items were randomly ordered, background questions (see Appendix 1 Part 1) were added.

\subsubsection{Speaking Test}

The speaking test was a face-to-face oral interview with one interviewer, consisting of two tasks: a role play and a question and answer session (QA). Since the role play was strictly based on what students learned in class, only the QA was used as a measure of proficiency. During the QA, the interviewer selected various topics and questions from a list. Since all the topics, such as food and club activities, were closely related to students' lives, it was assumed that there would be no difference in the level of difficulty between them. All utterances were tape-recorded and videotaped.

\subsection{Scoring the Speaking Test}

Upon completion of the speaking test, the assessment criteria were specified: Vocabulary, Comprehensibility, Accuracy, Complexity, and Interaction. A total of four points were given for each criterion (see Koizumi, 2001 for details). The raters were two Japanese non-native speakers of English, who majored in English while attending graduate school, and one native speaker, who worked as an English teacher in various junior high schools. After the raters were trained, one rater (the author) evaluated all of the examinees' utterances and the other two raters did half of them. In other words, each test taker was evaluated by two of the three raters.

\subsection{Analyses}

For each test and questionnaire, the internal consistency reliability estimates (Cronbach's alpha: $\alpha$ ) were calculated. In order to examine the research question, structural equation modeling (SEM) was used because it enables researchers in a flexible way to construct a model that reflects the existing knowledge (Yamamoto, 1999). In this study, the relationships between L2 proficiency and three affective factors (i.e., motivation, language anxiety, and test anxiety) were specified into a hypothesized model, which was examined using SEM. For the analyses, SPSS 10.0 and Amos 4.01 for Windows were used.

\section{Results}

\subsection{Questionnaire}

In order to check the validity of students' answers, four lie scale items were examined. It was decided that if there were students who met all of the criteria set forth 
(see Appendix 1 for the criteria), their data would be subsequently excluded from the analysis. None of the students satisfied the criteria, so all the data were used. Since the lie scale items were intended just for this purpose, they were not analyzed further.

After the deletion of the lie scale items, the questionnaire consisted of 60 items representing three affective factors: motivation, language anxiety, and test anxiety. Out of the 60,16 were eliminated as a result of being skewed items (see Appendix 1 Note for details) because skewed items can distort the results (Tanaka, 1996). The remaining items were 6 for motivation, 5 for language anxiety, and 33 for test anxiety. The motivation and language anxiety items were put into the causal model directly (see Figure 2). Both affective factors had a high reliability overall (Motivation $\alpha=.89$; Language anxiety $\alpha=.79$ ). The test anxiety items were further analyzed due to the fact that they were derived from four different sources.

Exploratory factor analysis ${ }^{4}$ was performed in order to clarify what 33 various test anxiety items measured and to select the items that contributed substantially to underlying factors. The following method was determined from Maeda's (2000) criteria. Nine factors were extracted based upon the eigenvalues of 1.0 or above through unweighted least squares method, and then rotated using oblique promax method. Table 2 shows the rotated pattern matrix and correlation matrix among these factors. Items with factor loadings of 0.4 or above were selected (Tanaka, 1996). Based on the scree plot and the interpretation of factors from previous studies, the first four factors were determined to be of use, which accounted for $38.25 \%$ of the total variance. Based on Sarason (1984), they were subsequently called Worry, Bodily arousal, Facilitating anxiety, and Test-irrelevant thinking, respectively. Factor 3 contained only two items and the reliability of Factor 4 was rather low $(\alpha=.59)$, but they were retained because certain aspects of facilitating anxiety (Factor 3 ) and test-irrelevant thinking (Factor 4) are important components of test anxiety (Alpert \& Harber, 1960; Sarason, 1984).

The items that did not load highly on any of the four factors were excluded. The remaining 20 items and their relationships to the four factors were put into a model of confirmatory factor analysis to verify the appropriacy of the four factors extracted by exploratory factor analysis.

In the path model (see Figure 1), rectangles show measured (observed) variables, which can be assessed directly. Ovals indicate latent variables, which cannot be directly assessed and are equal to factors in the factor analysis. Circles represent measurement errors. One-way arrows show a direct impact and the figures beside them are causal (path) coefficients, indicating the degree of impact. Two-way curved arrows show that two variables are correlated, and the figures close to them are the same as correlation coefficients. The two types of coefficients range from -1.00 to 1.00 in the standardized solution. 
Table 2 Results of Exploratory Factor Analysis

\begin{tabular}{|c|c|c|c|c|c|c|c|c|c|c|c|c|c|c|c|c|c|}
\hline & F1 & F2 & F3 & F4 & F5 & F6 & F7 & F8 & F9 & Com & $\alpha$ & $r$ & F1 & F2 & F3 & F4 & F5 \\
\hline TA45 & $\underline{0.83}$ & -0.03 & 0.18 & -0.10 & 0.14 & 0.08 & -0.03 & -0.07 & -0.20 & 0.65 & & F1 & 1.00 & & & & \\
\hline TA63 & $\underline{0.83}$ & 0.11 & -0.10 & -0.09 & -0.23 & -0.01 & 0.01 & 0.15 & 0.04 & 0.69 & & F2 & 0.41 & 1.00 & & & \\
\hline TA26 & $\underline{0.72}$ & -0.20 & 0.02 & -0.11 & -0.11 & -0.05 & -0.05 & -0.06 & 0.02 & 0.36 & & F3 & -0.12 & -0.26 & 1.00 & & \\
\hline TA47 & $\underline{0.63}$ & -0.06 & 0.18 & 0.20 & 0.13 & 0.07 & 0.00 & -0.09 & 0.21 & 0.71 & & F4 & 0.35 & 0.30 & -0.35 & 1.00 & \\
\hline TA 9 & $\underline{0.61}$ & 0.05 & 0.01 & -0.14 & 0.09 & -0.06 & -0.09 & 0.22 & -0.28 & 0.37 & 0.86 & F5 & 0.38 & 0.45 & -0.04 & 0.02 & 1.00 \\
\hline TA29 & $\underline{0.59}$ & -0.06 & -0.01 & -0.06 & 0.01 & -0.17 & 0.14 & -0.21 & 0.24 & 0.46 & & F6 & 0.37 & 0.34 & -0.32 & 0.48 & 0.11 \\
\hline TA19 & $\underline{0.56}$ & -0.19 & -0.07 & 0.29 & 0.09 & 0.06 & -0.05 & -0.05 & 0.08 & 0.52 & & F7 & 0.30 & 0.07 & -0.01 & 0.25 & 0.09 \\
\hline TA36 & $\underline{0.52}$ & 0.16 & -0.19 & -0.14 & 0.12 & -0.09 & 0.23 & -0.14 & -0.14 & 0.49 & & F8 & 0.13 & 0.13 & 0.13 & -0.02 & 0.16 \\
\hline TA 7 & $\underline{0.50}$ & -0.01 & -0.09 & 0.34 & -0.12 & 0.07 & 0.13 & 0.10 & -0.31 & 0.67 & & F9 & 0.34 & 0.25 & -0.02 & -0.12 & 0.45 \\
\hline TA17 & 0.50 & 0.08 & 0.10 & 0.28 & -0.15 & -0.02 & -0.04 & -0.03 & -0.07 & 0.38 & & & & & & & \\
\hline TA 3 & -0.18 & $\underline{0.67}$ & 0.25 & 0.32 & -0.05 & 0.01 & 0.27 & -0.13 & 0.02 & 0.60 & & $r$ & $\mathrm{~F} 6$ & F7 & F8 & F9 & \\
\hline TA 6 & -0.17 & $\underline{0.65}$ & -0.11 & 0.02 & -0.01 & 0.09 & 0.02 & -0.08 & -0.02 & 0.45 & & F6 & 1.00 & & & & \\
\hline TA16 & -0.12 & $\underline{0.58}$ & -0.01 & 0.19 & 0.11 & -0.05 & -0.03 & -0.01 & -0.13 & 0.40 & 0.71 & F7 & 0.17 & 1.00 & & & \\
\hline TA38 & 0.27 & $\underline{0.47}$ & 0.10 & -0.06 & -0.24 & 0.05 & -0.09 & -0.24 & 0.07 & 0.31 & & F8 & -0.12 & -0.13 & 1.00 & & \\
\hline TA50 & 0.11 & 0.40 & -0.07 & -0.05 & 0.11 & 0.20 & 0.00 & 0.01 & 0.00 & 0.39 & & F9 & 0.10 & -0.10 & 0.23 & 1.00 & \\
\hline TA60 & 0.12 & -0.03 & $\underline{0.89}$ & -0.06 & -0.03 & 0.12 & -0.14 & -0.14 & 0.17 & 0.80 & & & & & & & \\
\hline TA43 & -0.03 & 0.09 & 0.73 & -0.19 & 0.10 & 0.01 & 0.01 & 0.03 & 0.03 & 0.66 & 0.82 & & & & & & \\
\hline TA46 & 0.13 & -0.12 & 0.07 & -0.72 & -0.11 & 0.27 & 0.11 & 0.08 & 0.02 & 0.45 & & & & & & & \\
\hline TA56 & 0.10 & -0.11 & 0.28 & $\underline{-0.53}$ & 0.18 & 0.07 & 0.12 & -0.06 & -0.08 & 0.44 & 0.59 & & & & & & \\
\hline TA13 & 0.13 & -0.17 & -0.20 & 0.44 & 0.12 & 0.17 & 0.19 & -0.08 & 0.08 & 0.58 & & & & & & & \\
\hline TA64 & 0.17 & 0.07 & -0.05 & 0.33 & 0.04 & 0.05 & 0.00 & 0.29 & 0.13 & 0.41 & & & & & & & \\
\hline TA 8 & -0.05 & -0.14 & 0.23 & -0.32 & -0.05 & 0.00 & 0.02 & 0.05 & 0.24 & 0.34 & & & & & & & \\
\hline TA57 & -0.14 & -0.05 & 0.12 & 0.04 & $\underline{0.94}$ & 0.08 & 0.06 & -0.02 & -0.10 & 0.73 & & & & & & & \\
\hline TA22 & 0.11 & 0.09 & -0.09 & 0.05 & $\underline{0.52}$ & 0.06 & -0.10 & 0.07 & 0.22 & 0.63 & & & & & & & \\
\hline TA44 & 0.24 & 0.29 & 0.01 & 0.03 & 0.30 & -0.25 & -0.09 & -0.26 & 0.08 & 0.39 & & & & & & & \\
\hline TA54 & -0.05 & 0.10 & 0.10 & -0.25 & 0.07 & 1.00 & 0.03 & 0.06 & -0.05 & 0.82 & & & & & & & \\
\hline TA35 & 0.02 & 0.03 & 0.09 & -0.10 & -0.08 & 0.07 & $\underline{0.68}$ & 0.15 & 0.17 & 0.47 & & & & & & & \\
\hline TA 2 & -0.05 & 0.03 & -0.23 & -0.07 & 0.09 & -0.04 & $\underline{0.50}$ & -0.02 & 0.04 & 0.28 & & & & & & & \\
\hline TA18 & -0.09 & -0.16 & -0.08 & -0.08 & -0.04 & 0.05 & 0.07 & $\underline{0.46}$ & -0.01 & 0.21 & & & & & & & \\
\hline TA37 & 0.06 & -0.12 & 0.33 & 0.00 & 0.06 & -0.43 & 0.15 & $\underline{0.43}$ & 0.13 & 0.71 & & & & & & & \\
\hline TA 4 & 0.10 & 0.20 & 0.07 & 0.19 & 0.06 & 0.06 & -0.18 & 0.28 & -0.04 & 0.28 & & & & & & & \\
\hline TA27 & -0.06 & -0.06 & 0.16 & 0.01 & -0.03 & -0.06 & 0.10 & -0.02 & $\underline{0.47}$ & 0.22 & & & & & & & \\
\hline TA41 & 0.13 & 0.29 & -0.13 & -0.18 & 0.07 & 0.09 & 0.08 & 0.18 & 0.35 & 0.53 & & & & & & & \\
\hline RSSL & 5.60 & 3.79 & 2.81 & 3.53 & 2.84 & 2.99 & 1.61 & 1.11 & 1.79 & & & & & & & & \\
\hline & .70 & 39 & & & 41.22 & 43.78 & 46.18 & 48.22 & 19.79 & & & & & & & & \\
\hline
\end{tabular}

Note. Extraction Method: Unweighted Least Squares. Rotation Method: Promax with Kaiser Normalization. Rotation converged in 13 iterations. F = Factor; RSSL $=$ Rotation Sums of Squared Loadings; Cumu = Cumulative $\% ; r=$ correlations among the factors. When the internal consistency reliability $(\alpha)$ was calculated, scores from the negatively loaded items were inverted. Factors 1 to 4 were used for later analysis. Kaiser-Meyer-Olkin Measure of Sampling Adequacy $=.76$ (.50 or above as adequate). F1: Worry; F2: Bodily arousal; F3: Facilitating anxiety; F4: Test-irrelevant thinking. 


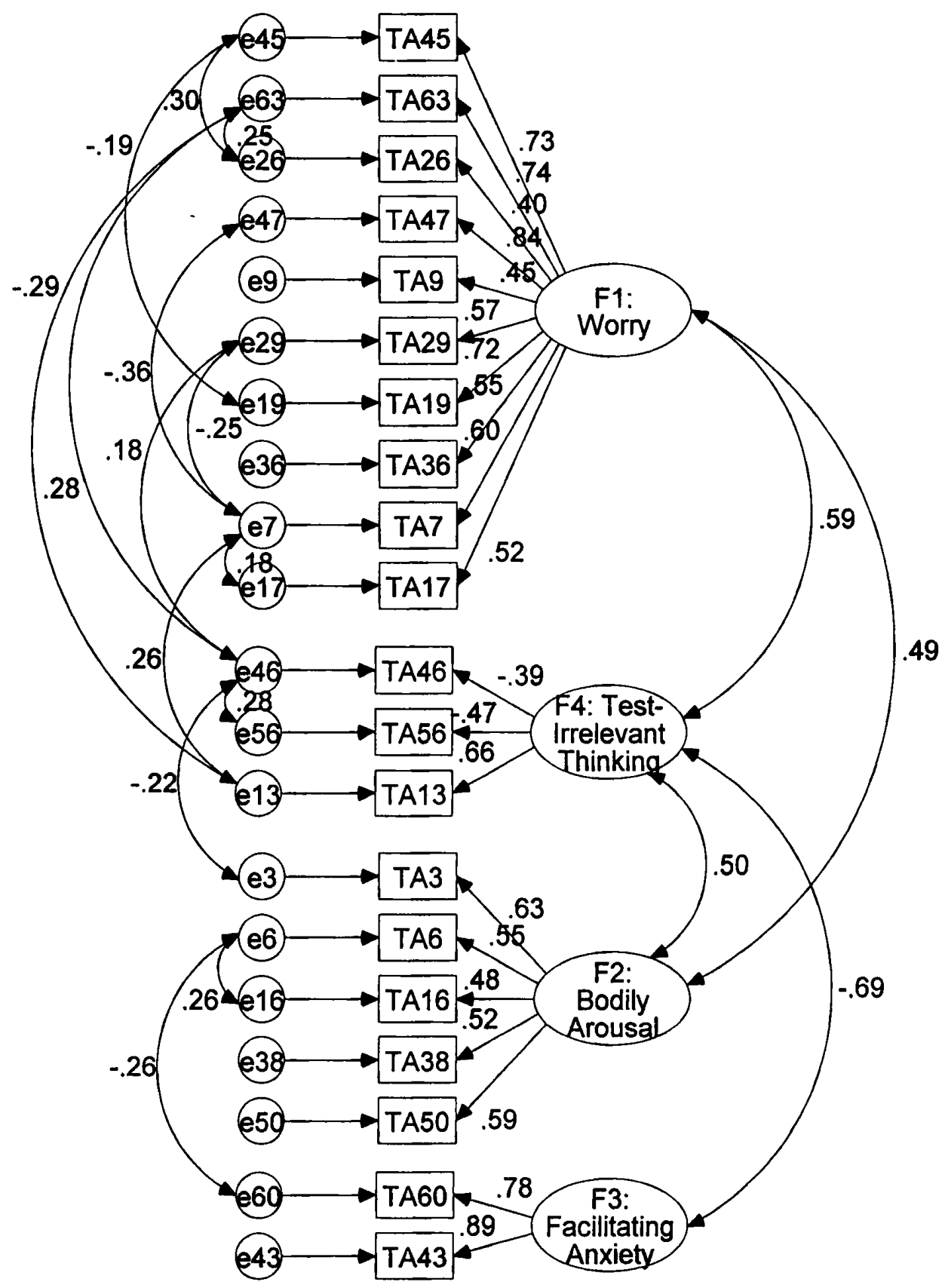

Figure 1 Result of Confirmatory Factor Analysis [Standardized Solution] Note. $N=129, \chi^{2}=183.65, d f=152, p=.04, \chi^{2} / d f$ (chi-square per degree of freedom ratio) $=1.21$, GFI (Goodness of Fit Index) $=0.88$, CFI (Comparative Fit Index) $=0.96$, RMSEA (Root Mean Square Error of Approximation) $=0.04$, AIC (Akaike Information Criterion) 299.65. Correlation coefficients are primarily shown outside the paths, except for the paths of e63-e26, e29-e7, and e46-e56. F = Factor; TA = Test anxiety.

For model estimation, maximum likelihood method was used. The model with 
two-way arrows between the four factors and also without any two-way arrows among measurement errors had the following chi-square goodness-of-fit statistic and fit indices: $\chi^{2}=287.87, d f=164, p=.00, \chi^{2} / d f=1.76, \mathrm{GFI}=0.82, \mathrm{CFI}=0.85$, $\mathrm{RMSEA}=0.08, \mathrm{AIC}=379.87$ (see Figure 1 Note. for the meaning of abbreviations). The criteria for being a good model are as follows: $p \geqq .05$ (i.e., a nonsignificant $\chi^{2}$ ); $\chi^{2} / d f<2.0$; CFI $>.90$ (Tabachnick \& Fidell, 1996); GFI > .90; RMSEA < .05; and smaller amount of AIC than other models in comparison (Toyoda, 1998). Since this study had a relatively small sample size for SEM, two criteria that do not underestimate model fit were used: $\chi^{2} / d f$ and CFI. With these two criteria, it was found that the first model did not fit the data very well.

In order to improve the degree of fit, the model was respecified using modification indices. The final model can be seen in Figure 1, which satisfied the two criteria above. The model suggests that there are moderate correlations between Worry, Test-irrelevant thinking, and Bodily arousal and also between Test-irrelevant thinking and Facilitating anxiety. Scores from negatively worded items were inverted and composite scores for each factor in the four-factor model were calculated in order to simplify the model that examines the research question (see Table 3).

Table 3 Descriptive Statistics of the Four Factors of Test Anxiety

\begin{tabular}{|c|c|c|c|c|c|c|c|}
\hline & Mean & $S D$ & Skew & Kurtosis & Minimum & Maximum & Full \\
\hline Worry Factor (10 items) & 30.23 & 8.85 & -0.06 & -0.71 & 10 & 50 & 50 \\
\hline Bodily Arousal (5 items) & 12.80 & 4.08 & 0.27 & -0.15 & 5 & 24 & 25 \\
\hline Facilitating Anxiety ( 2 items) & 6.19 & 1.96 & -0.19 & -0.26 & 2 & 10 & 10 \\
\hline Test-Irrelevant Thinking ( 3 items) & 9.74 & 2.39 & 0.34 & -0.23 & 4 & 15 & 15 \\
\hline
\end{tabular}

Note. $N=129$. Skew $=$ Skewness; Full $=$ Full marks.

\subsection{Proficiency Tests}

The two tests (the STEP Test and speaking test) were analyzed to estimate overall proficiency.

Table 4 Descriptive Statistics of the STEP Test and Speaking Test

\begin{tabular}{lrrrrrrr}
\hline & Mean & \multicolumn{1}{c}{ SD } & Skewness & Kurtosis & Minimum & Maximum & $\alpha$ \\
\hline STEP Test & 35.40 & 10.22 & -0.80 & -0.42 & 8 & 48 & 0.94 \\
Speaking Test (Total) & 16.88 & 6.55 & 0.72 & -0.29 & 8 & 32 & 0.82 \\
Vocabulary & 3.36 & 1.96 & 1.27 & 0.33 & 2 & 8 & \\
Comprehensibility & 5.97 & 1.92 & -0.69 & -0.70 & 2 & 8 & \\
Complexity & 4.56 & 2.38 & 0.24 & -1.52 & 2 & 8 & \\
Interaction & 2.99 & 1.79 & 1.80 & 2.09 & 2 & 8 & \\
\hline
\end{tabular}

Note. $N=129$. Maximum equals full marks. 


\subsubsection{STEP Test}

After the item analysis, two items were excluded because their discriminability was below .25 in point-biserial correlations (Henning, 1987). The remaining 48 items were used in the analysis. The STEP Test was considered to have sufficient validity. As seen in Table 4, the STEP Test had acceptable reliability $(\alpha)$ and the students scored rather high on the STEP Test.

\subsubsection{Speaking Test}

Interrater reliability of the scores was calculated using Spearman's rank order correlations due to the fact that the distribution of the scores from each rater was not normally distributed. The reliability was high except for Accuracy (Vocabulary: $r_{s}$ $=.92$; Comprehensibility: $r_{s}=.74$; Accuracy: $r_{s}=.49$; Complexity: $r_{s}=.87$; Interaction $\left.r_{s}=.83\right)$. Therefore, it was decided that Accuracy would be excluded from the subsequent analysis. The speaking test score was obtained by adding the criterion scores of the two raters.

Table 5 Internal Construction Validation, Using Spearman Rank-Order Correlations

\begin{tabular}{lccc}
\hline & Speaking Test Total & $>$ (Hypothesis) & STEP Test \\
\hline Vocabulary & $0.69^{*}$ & $>$ & $0.43^{*}$ \\
Comprehensibility & $0.41^{*}$ & $>$ & $0.40^{*}$ \\
Complexity & $0.54^{*}$ & $>$ & $0.50^{*}$ \\
Interaction & $0.62^{*}$ & $>$ & $0.32^{*}$ \\
\hline
\end{tabular}

Note. $N=129$. Speaking Test Total $=$ The total score in which the criterion in question was excluded. ${ }^{*} p<.05$; two-tailed.

The validity of the speaking test was examined using internal construct validation method. According to Henning (1987), items are valid when the correlation between item $A$ in subtest $B$ and a total of the other items in subtest $B$ is higher than the correlation between item $A$ and a total of another subtest. In the present study, the speaking test was viewed as one subtest, consisting of four items, or criteria: Vocabulary, Comprehensibility, Complexity, and Interaction. The STEP Test was perceived of as another subtest. The correlation between a speaking criterion (e.g., Vocabulary) and the total of the other three criteria was expected to be higher than the one between the criterion in question and the STEP Test. Table 5 shows that in each case the hypotheses were confirmed. Therefore, the construct validity of the speaking test was considered sufficiently high.

Table 4 demonstrates that the reliability $(\alpha)$ of the speaking test was high, along with that of the STEP Test. The students scored rather low on the speaking test, especially in the areas of Vocabulary and Interaction. 


\subsection{Model of the Relationships Between Affective Factors and L2 Proficiency}

In order to investigate motivation, language anxiety, and test anxiety as factors that affect proficiency, the causal relationships were specified in the path model. It was hypothesized that motivation, language anxiety, and test anxiety have an effect on L2 proficiency and that there are correlations between the three affective factors.

After the SEM analysis, it was found that the model did not fit the data well enough $\left(x^{2}=386.89, d f=113, p=.00, x^{2} / d f=3.42, \mathrm{GFI}=0.74, \mathrm{CFI}=0.73\right.$, $\mathrm{RMSEA}=0.14, \mathrm{AIC}=466.89)$. Following modification indices, two-way arrows between motivation and language anxiety and also between motivation and test anxiety were deleted, and the ones among measurement errors were added.

Figure 2 provides the best-fitting model that satisfied the two criteria (i.e., $\chi^{2} / d f$ and CFI). The model is considered a good fit. Every coefficient in the model was statistically significant at the .05 level.

As seen in Figure 2, the causal coefficients of motivation, language anxiety, and test anxiety were $.49, .21$, and -.29 respectively. There was a low correlation (.39) between language anxiety and test anxiety. In terms of the effects that motivation, language anxiety, and test anxiety had on each measured variable (e.g., M1), every causal coefficient was relatively high. This result suggests that these items of the three affective factors were sufficiently valid.

\section{Discussion}

The purpose of this study was to examine to what extent motivation, language anxiety, and test anxiety influence second language (L2) proficiency. The model that specified the relationships was formulated and modified until it showed a good fit (see Figure 2).

Concerning the impact of motivation on L2 proficiency, there was a significant and relatively strong effect, and its effect was greater than that of language anxiety and test anxiety. The results show that motivation affects the proficiency of Japanese junior high school students considerably and more than language anxiety and test anxiety. In other words, if students have strong motivation, it is likely that they will achieve a high level of proficiency, and this tendency is stronger than anxiety. This result is consistent with most of the previous studies (e.g., Gardner, 1985) and the degree of impact (.49) is very similar to those of Yamashiro and McLaughlin (2001) and Gardner et al. (1997), whose causal coefficients were .51 and .48. Yamashiro and McLaughlin examined the effect on the L2 proficiency of Japanese university students, whereas Gardner et al. investigated the impact on the L2 achievement of Canadian university students. Therefore, the results might suggest that motivation itself has a universal influence on students' L2 ability both in terms of proficiency and achievement. This hypothesis needs to be tested in other contexts.

Along with motivation, the causal coefficients of language anxiety and test 


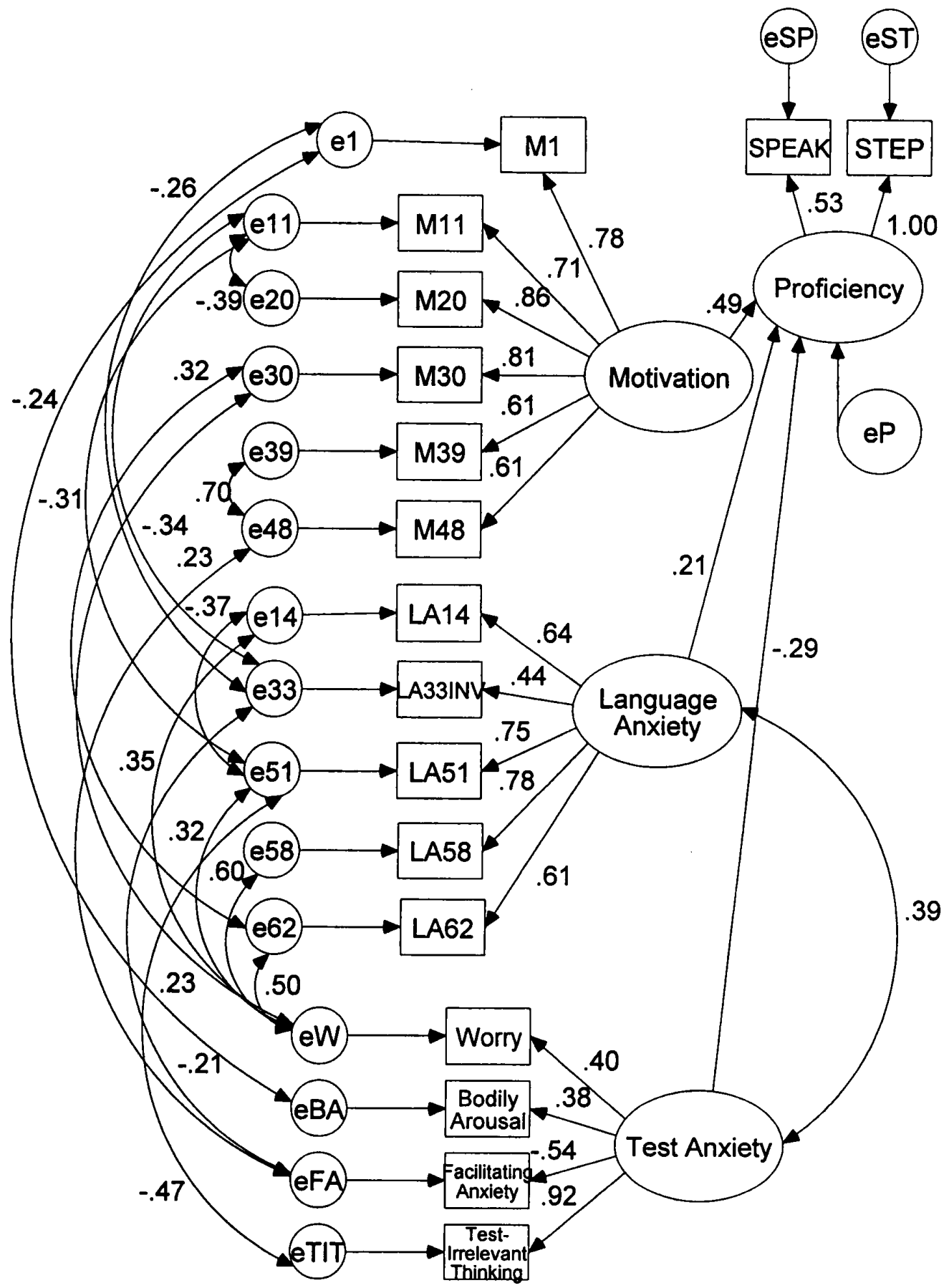

Figure 2 Result of Structural Equation Modeling [Standardized Solution]

Notes. $N=129, \chi^{2}=192.02, d f=99, p=.00, \chi^{2} / d f$ (chi-square per degree of freedom ratio) $=1.94$, GFI (Goodness of Fit Index) $=0.85$, CFI (Comparative Fit Index) $=0.91$, RMSEA (Root Mean Square Error of Approximation) $=0.09$, AIC (Akaike Information Criterion) $=$ 300.02. Correlation coefficients are basically shown outside the paths, except for the paths of e11-e33, e33-eFA, and e62-eW. $M=$ Motivation; LA = Language anxiety; INV = Inverted item; SPEAK = the Speaking Test; STEP = the STEP Test. 
anxiety were statistically significant, but they were very small. With respect to language anxiety, there was a small but positive influence (.21), whereas test anxiety had a small negative effect on L2 proficiency (-.29). The results indicate that two kinds of anxiety affect L2 proficiency only slightly.

Additionally, a significant relationship between the three affective factors was found between the two types of anxiety, which had a weak correlation (.39). Since the relationship was not very strong, they can be distinguished from each other. This suggests that test anxiety is rather different from language anxiety, consistent with the claim made by MacIntyre and Gardner (1989) and Aida (1994).

Based on these findings, it is clear that motivation is influential in developing L2 proficiency. Therefore, it is crucial for teachers to try to enhance students' motivation as well as to improve their L2 proficiency directly.

Finally, it may be necessary to note three limitations to this study. First, the scope of motivation and language anxiety in this study was admittedly rather limited. Motivation included only those items associated with attitudes toward learning English, and language anxiety had only those items to assess communication apprehension. Therefore, further refined research is needed to investigate the model in order to present a clearer picture in terms of the relationships between affective factors and L2 learning among Japanese junior high school students.

Second, the questionnaire contained 64 items, which might have been too many for junior high school students. Third and lastly, this study used self-report data obtained from the questionnaire, as previous studies do (e.g., Gardner et al., 1997; Yamashiro \& McLaughlin, 2001). It may have a validity problem, in that respondents may not recognize their affective states and may answer based on what they think they should feel (Ellis, 1994). The second and third problems can be overcome by a refined pilot-study to narrow down the number of items and by using multiple measures, including qualitative methods.

In summary, this study attempted to investigate the effects of motivation, language anxiety, and test anxiety on the second language proficiency of Japanese junior high school students. Among these students, motivation influences L2 proficiency considerably, and the effects of test anxiety and language anxiety are small. Test anxiety and language anxiety are weakly correlated. It is hoped that understanding the impact of motivation, language anxiety, and test anxiety may help teachers enhance their recognition of the students' learning process and improve their teaching styles.

\section{Acknowledgements}

I am deeply indebted to Professor Akihiko Mochizuki at University of Tsukuba for his useful suggestions and encouragement in conducting this experiment. I am also thankful to Professor John Shillaw, Professor Yuji Ushiro, and Professor Akiyo Hirai, all at University of Tsukuba, for their constructive comments. I would also wish to 
thank Mr. Yo In'nami, Mr. Koya Suzuki, Mr. Daniel Keola Pascal Jr., and Mr. David Klapper for their help.

\section{Notes}

1. According to Kunnan (1998), "establishing causality from correlations is not the focus of SEM" (p. 310). What SEM does is to "express causal relationships in a mathematical model and test a hypothesis reflected in the model by examining that model to see that it does not contradict the data" (Yamamoto, 1999, p. 7, translated by the author).

2. Gardner et al. (1997) also included an anxiety measure in their model but it was a component of self-confidence.

3. Yamashiro and McLaughlin's (2001) "anxiety" can be considered language anxiety.

4. There are two types of factor analysis: exploratory and confirmatory factor analysis. The former is designed to explore and identify factors underlying the data, while the latter attempts to verify if a model of the factors fits the data and can be statistically confirmed.

\section{References}

Aida, Y. (1994). Examination of Horwitz, Horwitz, and Cope's construct of foreign language anxiety: The case of students of Japanese. Modern Language Journal, 94, 155-168.

Alpert, R., \& Harper, R. N. (1960). Anxiety in academic achievement situations. Journal of Abnormal and Social Psychology, 61, 207-215.

Araki, N. (1991). A study of test anxiety in elementary school and junior high school students in Japan: Sex differences, developmental trends and influences on academic achievements. 『兵庫教育大学研究紀要 第 1 分冊 (学校教育 - 幼児教育・障害児 教育)』, 11, 47-61.

Araki, N., Sato, S., \& Nei, M. (1979). A study on standardization of Test Anxiety Scale for Children: Item analysis and test of reliability. Memoirs of the Faculty Education Miyazaki University Humanities Science, 45, 15-28.

Berwick, R., \& Ross, S. (1989). Motivation after matriculation: Are Japanese learners of English still alive after exam hell? JALT Journal, 11, 193-210

Cornwell, S., \& McKay, T. (2000). Establishing a valid, reliable measure of writing apprehension for Japanese students. JALT Journal, 22, 114-139.

Eysenck, M. W., \& M. G. Calvo. (1992). Anxiety and performance: The processing efficiency theory. Cognition and Emotion, 6, 409-434.

Ellis, R. (1994). The study of second language acquisition. Oxford University Press.

Fujii, Y. (1993). Construction of a Test Influence Inventory (TII). Japanese Journal of Psychology, 64, 135-139.

Gardner, R. C. (1985). Social psychology and second language learning: The role of attitudes and motivation. London: Edward Arnold.

Gardner, R. C., \& MacIntyre, P. D. (1993). A student's contributions to second language learning Part II : Affective variables. Language Teaching, 26, 1-11.

Gardner, R. C., Tremblay, P. F., \& Masgoret, A. M. (1997). Towards a full model of second 
language learning: An empirical investigation. Modern Language Journal, 81, 344-362. Henning, G. (1987). A guide to language testing: Development, evaluation, research. Boston, MA: Heinle \& Heinle.

Horwitz, E. K. (1986). Preliminary evidence for the reliability and validity of a foreign language anxiety scale. TESOL Quarterly, 20, 559-562.

Horwitz, E. K. (2001). Language anxiety and achievement. Annual Review of Applied Linguistics, 21, 112-126.

Horwitz, E. K., Horwitz, M. B., \& Cope, J. (1986). Foreign language classroom anxiety. Modern Language Journal, 70, 125-132.

Katanoda, H. (1995). Anxiety and second language learning. Annual Review of English Language Education in Japan, 6, 135-144.

Kimura, Y., Nakata, Y., \& Okumura, T. (2001). Language learning motivation of EFL learners in Japan-A cross-sectional analysis of various learning milieus. JALT Journal, 23, 47-68.

Koizumi, R. (2001). Anxiety with Speaking Tests for Junior High School Students in Japan. Unpublished master's thesis, University of Tsukuba.

Kunnan, A. J. (1998). An introduction to structural equation modelling for language assessment research. Language Testing, 15, 295-332.

Macintyre, P. D., \& Gardner, R. C. (1989). Anxiety and second-language learning: Toward a theoretical clarification. Language Learning, 39, 251-275.

Maeda, H (前田啓朗). (2000). 「構成概念の妥当性の検証一日本の英語教育学研究にお ける傾向と展望一] [Investigating the construct validity: Tendencies and perspectives in English language learning education studies in Japan]. JLTA Journal, 3, 119-126.

Matsuda, S., \& Gobel, P. (2001). Quiet apprehension: Reading and classroom anxieties. JALT Journal, 23, 227-247.

Phillips, E. M. (1992). The effects of language anxiety on students' oral test performance and attitudes. Modern Language Journal, 76, 14-26.

Sarason, I. G. (1984). Stress, Anxiety, and Cognitive Interference: Reactions to Tests. Journal of Personality and Social Psychology, 46, 929-938.

Sawaki, Y. (1997). Japanese learners' language learning motivation: A preliminary study. JACET Bulletin, 28, 83-96.

Sparks, R. L., \& Ganschow, L. (1995). A strong inference approach to causal factors in foreign language learning: A response to MacIntyre. Modern Language Journal, 77, 235-244.

Tabachnick, B. G., \& Fidell, L. S. (1996). Using multivariate statistics (3rd ed.). NY: HarperCollins College.

Tachibana, Y., Matsukawa, R., \& Zhong, Q. X. (1996). Attitudes and motivation for learning English: A cross-national comparison of Japanese and Chinese high school students. Psychological Reports, 79, 691-700.

Tanaka, S (田中敏). (1996). 『実践心理データ解析 : 問題の発想・データ処理・論文の 作成』[Practical Method to Analyze Psychological Data: Selecting a Theme, Analyzing Data, and Writing a Paper]. 東京 : 新曜社.

Teweles, B. (1996). Motivational differences between Chinese and Japanese learners of English as a foreign language. JALT Journal, 18, 211-228.

Toyoda, H (豊田秀樹). (1998). 『共分散構造分析 [入門編]一構造方程式モデリング一』 [Introduction to Covariance Structure Analysis - Structural Equation Modeling一]. 東 京 : 朝倉畫店. 
Tremblay, P. F., \& Gardner, R. C. (1995). Expanding the motivation construct in language learning. Modern Language Journal, 79, 505-518.

Yamamoto, K (山本嘉一郎). (1999). 「共分散構造分析とその適用」 [Covariance structure analysis and its applications]. In 山本嘉一郎, \& 小野寺孝義 (編). 『Amos による共 分散構造分析と解析事例』(pp. 1-22). 京都 : ナカニシヤ出版.

Yamashiro, A. D., \& McLaughlin, J. (2001). Relationships among attitudes, motivation, anxiety, and English language proficiency in Japanese college students. In P. Robinson, M. Sawyer, \& S. Ross (Eds.), Second language acquisition research in Japan (pp. 113-127). Tokyo: Japan Association for Language Teaching.

Yashima, T. (2000). Orientations and motivation in foreign language learning: A study of Japanese college students. JACET Bulletin, 31, 121-133.

Yukina, K (行名一夫). (2000).「中学 $1 \cdot 2$ 年生の英語力と学習動機・態度・戦略の関係 一心理測定尺度の妥当性と信頼性の検証一] [The relationships between motivation, attitudes, learning strategy, and English proficiency of first and second-year junior high school students - Investigating the validity and reliability of psychological scales-]. STEP Bulletin, 12, 44-66.

Zeidner, M. (1998). Test anxiety: The state of the art. NY: Plenum Press.

\section{Appendix 1}

小・中学生の意識調查（しょう・ちゅうがくせいのいしきちょうさ）

注意点 : 英語の授業で、と書いてあるときは英語の授業中のこと、書いてないときは他の 教科の時間もあわせて考えて答えてください。また、ページを一度めくったら、前のペー ジにもとっってはいけません。全部の質問を、ならんでいる順に答えていってください。

Part 1 略 (Questions about students' gender, when they first began studying English, whether they have the opportunity to speak English outside of school, whether and how long they have been abroad)

Part 2 あなたの気持ちに一番近いものを○でかこんでください。
1. ぜんぜんそうでない
2. ほとんどそうでない 3. どちらともいえない
4. 少しそうだ
5. とてもそうだ

\section{Lie scale items (4 items)}

(2-28) ゲームをしたとき、勝ちたいと思います。(Criterion: 1 [If students choose "1," they are considered to be telling a lie.]) [TASC]

(2-31) 自分の知っている人をみんな好きです。(Criterion: 5) [TASC]

(2-34) 言わないという約束はぜったいに守ります。(Criterion: 5) [TASC]

(2-40) よい成績をとりたいと思います。(Criterion: 1) [TASC]

\section{Motivation (7 items)}

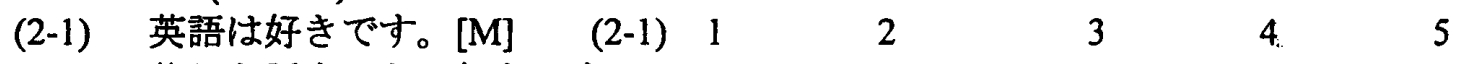

(2-11) 英語を話すことは好きです。[M] (the same format);

(2-20)＼cjkstart英語を勉強したいと思います。[M]

(2-30) 英語を話す練習をしたいと思います。[M]

(2-39) 英語を使う能力は自分にとって必要です。[M]

(2-48) 英語の、特に話す能力は自分にとって必要だと思います。[M]

(2-55) 英語は得意です。 $[\mathrm{M}$, skewed] 


\section{Language anxiety (7 items)}

(2-14) 英語の授業でとつぜん英語で話さなくてはならなくなるとパニックになりま す。 [FLCAS]

(2-23) アメリカ人・イギリス人などと英語で話すのはきんちょうします。 [FLCAS, skewed]

(2-33) 英語の授業中に英語を話すとき、自信をもってできます。[FLCAS，inverted]

(2-42) 自分より他の人の方が英語を話すのが上手だと思います。 [FLCAS, inverted, skewed]

(2-51) 他の人の前で英語を話すのははずかしいです。[FLCAS]

(2-58) 英語の授業で英語を話すとき、不安です。[FLCAS]

(2-62) 英語を話すとき他の人が自分をわらうのではないかと心配です。[FLCAS]

Test anxiety (Four factors: $38.255 \%$ of the variance explained)

Factor 1: Worry (10 items)

(2-45) テストを受ける前、とても心配になります。[TASC]

(2-63) 先生が「これからテストをします」と言うと、自分が悪い点をとるのではない かと心配になります。[TASC]

(2-26) 病気になって学校を休むとします。病気がなおって学校へ行けるようになった とき、勉強が他の人たちよりもずっとおくれているのではないかと心配になり ます。[TASC]

(2-47) テスト中、よく不安になります。[TII]

(2-9) テストが成績に入るのかどうかが気になります。[M]

(2-29) テスト中、よくきんちょうします。[TII]

(2-19) テスト中、よく自信がなくなります。[TII]

(2-36) 学校のテストがこわいです。[TASC]

(2-7) テスト中、何でこんなにできないのだろうと思います。[TASC]

(2-17) 夜、次の日の学校の勉強がうまくやれるかどうか心配になることがときどきあ ります。[TASC]

\section{Factor 2: Bodily arousal (5 items)}

(2-3) テスト中、よく頭がぼんやりします。[TII]

(2-6) テスト中、よくあくびが出ます。[TII]

(2-16) テスト中、よくねむくなります。[TII]

(2-38) テスト中、よくまわりの人のことが気になります。[TII]

(2-50) テスト中、よくいらいらします。[TII]

Factor 3: Facilitating anxiety (2 items)

(2-60) テストの前にテストに出そうなところを頭につめこんで、おぼえることができ ます。[AAS]

(2-43) テストの前につめこんでおぼえたことを、テスト中に使うことができます。 [AAS]

Factor 4: Test-irrelevant thinking (3 items)

(2-46) 成績が 1 回のテストで決まるとき、他の人よりいい点がとれると思います。 [AAS, inverted (not originally but in interpretation, it became the inverted item)]

(2-56) たいせつなテストだといい点がとれます。[AAS, inverted (same as 2-46)] 
(2-13) テスト中、よく何がなんだかわからなくなります。[TII]

Items that did not load on the four factors among test anxiety items (13 items)

(2-2) テスト中、よくまばたきをします。[M]

(2-4) テスト中、残り時間があと何分あるかが気になります。 [M]

(2-8) テストの問題がとても難しいときでも、スムーズにとくことができます。[AAS]

(2-18) テストの前に不安でも、はじまってしまうとその気持ちをわすれてしまいます。 [AAS]

(2-22) テスト中、よく目がつかれます。[TII]

(2-27) テスト中に不安だといい点がとれます。[AAS]

(2-35) テスト中、よく手にあせをかきます。[TII]

(2-37) テストが始まると集中できます。[AAS]

(2-41) テスト中、よく目がいたくなります。[TII]

(2-44) テスト中、よくのどがかわきます。[TII]

(2-54) テスト中、気がちります。[TII]

(2-57) テスト中、よく、かたがこります。[TII]

(2-64) テスト中、よく度忘れします。[TII]

\section{Skewed items (13 items)}

(2-5) 授業中、前に出て黒板に書くとき、手がふるえます。[TASC, skewed]

(2-10) テスト中、よく手がだるくなります。[TII, skewed]

(2-12) テストを受けているとき、書いている手がふるえます。[TASC, skewed]

(2-15) 先生にあてられてうまく答えられないと、泣きたい気持ちになります。 [TASC, skewed]

(2-21) テストをするときは前もって知らせてほしいと思います。 [M, skewed]

(2-24) 学校で受けたテストがよくできなかった、という夢を見ることがあります。 [TASC, skewed]

(2-25) テスト中、よく冷や汗が出ます。[TII, skewed]

(2-32) テスト中、よくトイレに行きたくなります。[TII, skewed]

(2-49) かんたんなテストより難しいテストをうけるほうが好きです。[AAS, skewed]

(2-52) 学校へ行くとちゅう、先生がテストをするかもしれないと心配になります。 [TASC, skewed]

(2-53) テストをうけるのは楽しみです。[AAS, skewed]

(2-59) テストをうけたあと、どのくらいよくできたか心配になります。[TASC, skewed]

(2-61) テスト中、よく胸がどきどきします。[TII, skewed]

Note. In the questionnaire, the items were ordered like this: (2-1), (2-2), (2-3) ... and (2-64).

[Source]: Made by author (M); Foreign Language Classroom Anxiety Scale (FLCAS); Test

Anxiety Scale for Children (TASC); Test Influence Inventory (TII); Achievement

Anxiety Scale (AAS)

[inverted] refers to an item negatively worded. The score was inverted in the analysis.

[skewed] means as follows: When the mean minus the $\mathrm{SD}(M-S D)$ was less than 1' (a possible minimum) or when the mean plus the $\mathrm{SD}(M+S D$ ) was more than 5 (a possible maximum), an item was regarded as skewed and excluded from the subsequent analysis (Tanaka, 1996). For example, TestAnx 15 (see Appendix 2) had a mean of 2.1 and a SD of 1.3. The mean plus the SD is $2.1+1.3=3.4$, which is below 5 and is not considered skewed, but the mean minus the SD is $2.1-1.3=0.8$, which is less than 1 , which leads 
to the deletion.

\section{Appendix 2}

Descriptive Statistics of the Questionnaire Items

\begin{tabular}{|c|c|c|c|c|c|c|c|c|c|}
\hline Item & Mean S & $S D$ & Skewness K & Irtosis & Item & Mean $s$ & $S D$ & Skewness K & rtosis \\
\hline Motivat 1 & 2.89 & 1.18 & -0.16 & -0.86 & TestAnx $21^{*}$ & 4.43 & 0.94 & -1.77 & 2.83 \\
\hline Motivat 11 & 2.81 & 1.26 & 0.13 & -0.88 & TestAnx 22 & 2.79 & 1.27 & 0.03 & -1.10 \\
\hline Motivat 20 & 2.97 & 1.20 & -0.11 & -0.64 & TestAnx 24* & 1.55 & 0.95 & 1.68 & 1.84 \\
\hline Motivat 30 & 3.02 & 1.30 & -0.17 & -1.01 & TestAnx 25* & 1.67 & 1.04 & 1.49 & 1.40 \\
\hline Motivat 39 & 3.70 & 1.18 & -0.56 & -0.41 & TestAnx 26 & 3.34 & 1.46 & -0.51 & -1.16 \\
\hline Motivat 48 & 3.57 & 1.22 & -0.49 & -0.58 & TestAnx 27 & 2.09 & 0.98 & 0.37 & -0.57 \\
\hline Motivat $55^{*}$ & 2.22 & 1.29 & 0.64 & -0.80 & TestAnx 29 & 2.74 & 1.26 & 0.17 & -0.97 \\
\hline $\operatorname{LanAnx} 14$ & 3.07 & 1.27 & -0.06 & -0.95 & TestAnx 32* & 1.56 & 0.90 & 1.78 & 2.95 \\
\hline LanAnx 23* & 4.29 & 1.08 & -1.47 & 1.33 & TestAnx 35 & 2.46 & 1.41 & 0.47 & -1.10 \\
\hline LanAnx 33 & 2.22 & 1.15 & 0.62 & -0.38 & TestAnx 36 & 2.65 & 1.44 & 0.27 & -1.25 \\
\hline LanAnx 42* & 4.04 & 1.17 & -1.00 & 0.09 & TestAnx 37 & 3.74 & 1.14 & -0.57 & -0.40 \\
\hline LanAnx 51 & 3.57 & 1.29 & -0.57 & -0.75 & TestAnx 38 & 2.31 & 1.22 & 0.58 & -0.71 \\
\hline LanAnx 58 & 3.28 & 1.34 & -0.27 & -1.08 & TestAnx 41 & 2.29 & 1.26 & 0.57 & -0.78 \\
\hline LanAnx 62 & 2.86 & 1.40 & 0.03 & -1.26 & TestAnx 43 & 3.22 & 1.06 & -0.34 & -0.31 \\
\hline TestAnx 2 & 2.62 & 0.89 & 0.03 & 0.13 & TestAnx 44 & 2.23 & 1.14 & 0.57 & -0.49 \\
\hline TestAnx 3 & 2.34 & 1.09 & 0.38 & -1.02 & TestAnx 45 & 3.34 & 1.39 & -0.44 & -1.06 \\
\hline TestAnx 4 & 3.81 & 1.13 & -1.09 & 0.46 & TestAnx 46 & 2.34 & 0.92 & -0.13 & -0.73 \\
\hline TestAnx 5* & 1.70 & 0.99 & 1.38 & 0.99 & TestAnx 47 & 2.85 & 1.35 & 0.00 & -1.19 \\
\hline TestAnx 6 & 2.71 & 1.13 & 0.27 & -0.75 & TestAnx 49* & 2.02 & 1.08 & 0.90 & 0.29 \\
\hline TestAnx 7 & 3.35 & 1.30 & -0.17 & -1.18 & TestAnx 50 & 2.33 & 1.22 & 0.51 & -0.84 \\
\hline TestAnx 8 & 2.22 & 1.00 & 0.27 & -0.84 & TestAnx 52* & 1.62 & 0.95 & 1.45 & 1.50 \\
\hline TestAnx 9 & 3.66 & 1.30 & -0.59 & -0.82 & TestAnx 53* & 1.91 & 1.06 & 0.79 & -0.39 \\
\hline TestAnx 10* & 1.84 & 1.00 & 1.15 & 0.89 & TestAnx 54 & 2.18 & 1.03 & 0.37 & -0.88 \\
\hline TestAnx 12* & 1.40 & 0.76 & 2.17 & 4.89 & TestAnx 56 & 2.51 & 0.94 & -0.12 & -0.38 \\
\hline TestAnx 13 & 2.60 & 1.31 & 0.30 & -1.12 & TestAnx 57 & 2.56 & 1.47 & 0.37 & -1.29 \\
\hline TestAnx 15* & 2.12 & 1.31 & 0.84 & -0.55 & TestAnx 59* & 4.09 & 1.12 & -1.33 & 1.17 \\
\hline TestAnx 16 & 3.11 & 1.34 & -0.08 & -1.17 & TestAnx 60 & 2.97 & 1.07 & 0.02 & -0.57 \\
\hline TestAnx 17 & 2.19 & 1.17 & 0.64 & -0.57 & TestAnx 61* & 2.26 & 1.34 & 0.62 & -0.93 \\
\hline TestAnx 18 & 3.50 & 1.11 & -0.42 & -0.32 & TestAnx 63 & 3.09 & 1.41 & -0.17 & -1.20 \\
\hline TestAnx 19 & 3.02 & 1.18 & 0.06 & -0.85 & TestAnx 64 & 3.01 & 1.16 & -0.17 & -0.84 \\
\hline
\end{tabular}

Note. $N=129$. All minimum $=1$; all maximum $=5$; Motivat $=$ Motivation; LanAnx $=$ Language Anxiety; TestAnx = Test Anxiety. ${ }^{*}$ refers to a skewed item (see Appendix 1 Note).

\section{Appendix 3}

Correlation Matrix of the Questionnaire (Pearson product-moment correlation)

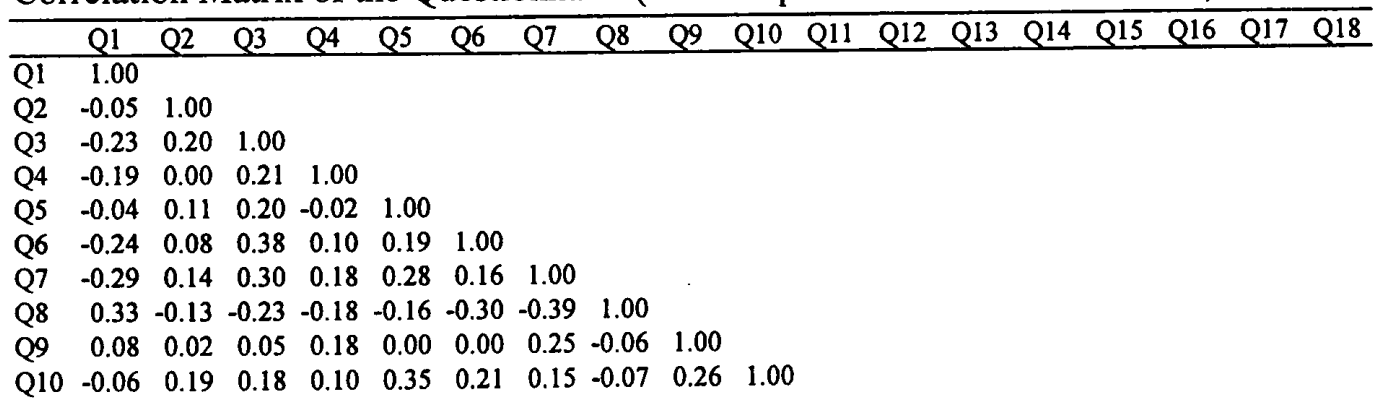


$\begin{array}{llllllllllllllllll}\mathrm{Q} 1 & \mathrm{Q} 2 & \mathrm{Q} 3 & \mathrm{Q} 4 & \mathrm{Q} 5 & \mathrm{Q} 6 & \mathrm{Q} 7 & \mathrm{Q} 8 & \mathrm{Q} & \mathrm{Q} 10 & \mathrm{Q} 11 & \mathrm{Q} 12 & \mathrm{Q} 13 & \mathrm{Q} 14 & \mathrm{Q} 15 & \mathrm{Q} 16 & \mathrm{Q} 17 & \mathrm{Q} 18\end{array}$

\begin{tabular}{llllllllllllllll}
\hline Q11 & 0.62 & -0.03 & -0.05 & -0.08 & -0.10 & -0.06 & -0.14 & 0.27 & 0.17 & 0.00 & 1.00
\end{tabular}

$\begin{array}{llllllllllllll}\text { Q12 } & 0.07 & 0.10 & -0.01 & 0.08 & 0.38 & -0.08 & 0.10 & 0.03 & 0.07 & 0.31 & -0.02 & 1.00\end{array}$

$\begin{array}{llllllllllllllll}\text { Q13 } & -0.31 & 0.17 & 0.27 & 0.04 & 0.31 & 0.17 & 0.54 & -0.30 & 0.13 & 0.27 & -0.13 & 0.21 & 1.00\end{array}$

$\begin{array}{lllllllllllllll}\text { Q14 } & -0.21 & 0.06 & 0.14 & 0.07 & 0.37 & 0.20 & 0.47 & -0.31 & 0.13 & 0.11 & -0.10 & 0.08 & 0.47 & 1.00\end{array}$

$\begin{array}{llllllllllllllll}\text { Q15 } & -0.02 & -0.09 & -0.08 & 0.03 & 0.25 & 0.14 & 0.22 & -0.10 & 0.14 & 0.12 & 0.09 & 0.00 & 0.28 & 0.42 & 1.00\end{array}$

$\begin{array}{lllllllllllllllll}\text { Q16 } & -0.22 & 0.05 & 0.38 & 0.19 & 0.17 & 0.47 & 0.16 & -0.24 & 0.13 & 0.17 & -0.14 & -0.10 & 0.20 & 0.12 & 0.09 & 1.00\end{array}$

$\begin{array}{llllllllllllllllll}\text { Q17 } & -0.02 & 0.12 & 0.24 & 0.15 & 0.11 & 0.08 & 0.48 & -0.22 & 0.27 & 0.19 & 0.03 & -0.05 & 0.38 & 0.35 & 0.33 & 0.22 & 1.00\end{array}$

$\begin{array}{lllllllllllllllllll}\text { Q18 } & 0.06 & -0.05 & -0.19 & 0.06 & -0.10 & -0.07 & -0.08 & 0.18 & 0.14 & 0.00 & 0.01 & -0.01 & -0.02 & 0.01 & -0.07 & -0.10 & -0.07 & 1.00\end{array}$ $\begin{array}{llllllllllllllllllll}\text { Q19 } & -0.13 & 0.13 & 0.12 & 0.18 & 0.22 & 0.14 & 0.46 & -0.24 & 0.35 & 0.21 & 0.08 & 0.14 & 0.42 & 0.36 & 0.17 & 0.07 & 0.37 & -0.05\end{array}$ $\begin{array}{lllllllllllllllllll}\text { Q20 } & 0.70 & -0.11 & -0.10 & -0.15 & 0.09 & -0.19 & -0.15 & 0.25 & 0.17 & 0.00 & 0.53 & 0.04 & -0.17 & 0.04 & 0.23 & -0.13 & 0.09 & -0.06\end{array}$

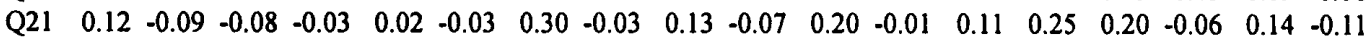
$\begin{array}{lllllllllllllllllll}\text { Q22 } & 0.00 & 0.11 & 0.23 & 0.29 & 0.12 & 0.23 & 0.06 & -0.14 & 0.25 & 0.34 & 0.03 & 0.11 & 0.22 & 0.15 & 0.16 & 0.22 & 0.15 & -0.05\end{array}$ $\begin{array}{lllllllllllllllllll}\text { Q23 } & 0.01 & 0.03 & 0.00 & 0.04 & 0.05 & 0.02 & 0.25 & -0.20 & 0.15 & -0.04 & 0.01 & 0.04 & 0.24 & 0.31 & 0.24 & 0.02 & 0.18 & -0.02\end{array}$

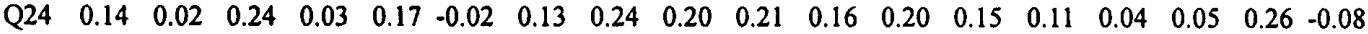
$\begin{array}{llllllllllllllllllll}\text { Q25 } & -0.07 & 0.28 & 0.26 & 0.16 & 0.21 & 0.14 & 0.24 & -0.04 & 0.14 & 0.21 & -0.02 & 0.19 & 0.30 & 0.25 & 0.12 & 0.13 & 0.19 & -0.02\end{array}$ $\begin{array}{lllllllllllllllllll}\text { Q26 } & 0.21 & 0.01 & -0.05 & 0.04 & 0.12 & -0.12 & 0.23 & 0.00 & 0.27 & 0.11 & 0.20 & -0.02 & 0.08 & 0.25 & 0.32 & -0.12 & 0.27 & -0.13\end{array}$ $\begin{array}{llllllllllllllllllll}\text { Q27 } & 0.07 & 0.01 & -0.02 & 0.00 & 0.01 & -0.07 & -0.21 & 0.11 & -0.02 & 0.18 & -0.02 & 0.02 & -0.02 & 0.09 & 0.12 & -0.10 & -0.02 & 0.03\end{array}$

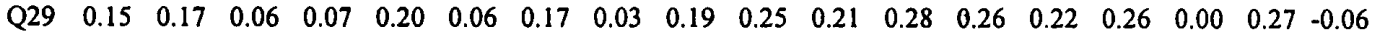

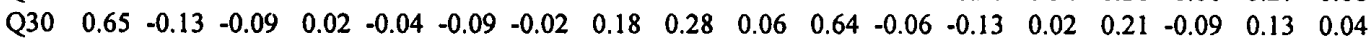

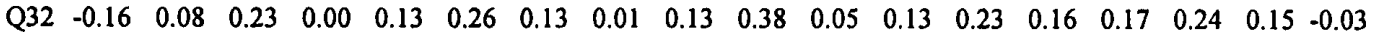
$\begin{array}{lllllllllllllllllll}\text { Q33 } & 0.52 & -0.11 & -0.16 & -0.15 & -0.15 & -0.12 & -0.34 & 0.43 & -0.04 & 0.01 & 0.51 & 0.00 & -0.41 & -0.39 & -0.15 & -0.16 & -0.26 & 0.05\end{array}$ $\begin{array}{lllllllllllllllllll}\text { Q35 } & 0.03 & 0.29 & 0.20 & -0.03 & 0.25 & -0.02 & 0.19 & 0.01 & 0.09 & 0.17 & -0.07 & 0.08 & 0.17 & 0.13 & 0.01 & 0.01 & 0.00 & 0.04\end{array}$ $\begin{array}{lllllllllllllllllll}\text { Q36 } & -0.15 & 0.22 & 0.29 & 0.07 & 0.18 & 0.20 & 0.36 & -0.19 & 0.28 & 0.28 & -0.10 & 0.18 & 0.31 & 0.18 & 0.12 & 0.15 & 0.27 & -0.13\end{array}$

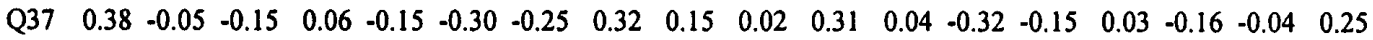

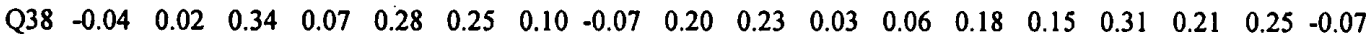
$\begin{array}{lllllllllllllllllll}\text { Q39 } & 0.47 & 0.02 & -0.14 & -0.15 & 0.03 & -0.08 & -0.13 & 0.18 & 0.10 & -0.11 & 0.42 & -0.01 & -0.16 & -0.04 & 0.14 & -0.20 & 0.14 & 0.03\end{array}$

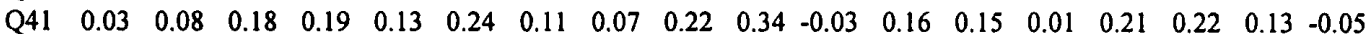
$\begin{array}{lllllllllllllllllll}\text { Q42 } & -0.18 & -0.06 & 0.07 & 0.24 & -0.02 & 0.03 & 0.20 & -0.05 & 0.08 & 0.02 & -0.12 & -0.04 & 0.07 & 0.02 & 0.09 & 0.00 & 0.18 & -0.03\end{array}$ $\begin{array}{lllllllllllllllllll}\text { Q43 } & 0.24 & -0.17 & -0.07 & -0.03 & -0.20 & -0.13 & -0.30 & 0.33 & 0.06 & -0.02 & 0.18 & -0.07 & -0.44 & -0.12 & -0.07 & -0.16 & -0.09 & 0.04\end{array}$ $\begin{array}{lllllllllllllllllll}\text { Q44 } & -0.08 & 0.03 & 0.18 & 0.14 & 0.15 & 0.22 & 0.09 & -0.07 & 0.21 & 0.37 & -0.02 & 0.04 & 0.11 & 0.13 & 0.16 & 0.22 & 0.08 & -0.22\end{array}$

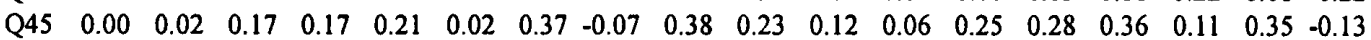
$\begin{array}{lllllllllllllllllll}\text { Q46 } & 0.20 & -0.01 & -0.32 & -0.18 & -0.05 & -0.17 & -0.25 & 0.28 & -0.03 & 0.03 & 0.14 & 0.04 & -0.29 & -0.07 & -0.05 & -0.23 & -0.15 & 0.12\end{array}$ $\begin{array}{lllllllllllllllllll}\text { Q47 } & -0.02 & 0.12 & 0.23 & 0.22 & 0.21 & 0.12 & 0.36 & -0.07 & 0.35 & 0.31 & 0.08 & 0.15 & 0.40 & 0.27 & 0.36 & 0.16 & 0.41 & -0.12\end{array}$ $\begin{array}{lllllllllllllllllll}\text { Q48 } & 0.45 & -0.05 & -0.05 & -0.23 & 0.07 & -0.01 & 0.02 & 0.09 & 0.09 & -0.05 & 0.45 & -0.05 & -0.04 & 0.03 & 0.17 & -0.16 & 0.21 & -0.03\end{array}$ $\begin{array}{lllllllllllllllllll}\text { Q49 } & 0.41 & 0.03 & -0.24 & -0.12 & -0.10 & 0.01 & -0.22 & 0.28 & 0.11 & -0.05 & 0.44 & 0.01 & -0.21 & -0.09 & -0.05 & -0.15 & -0.11 & 0.13\end{array}$ $\begin{array}{lllllllllllllllllll}\text { Q50 } & -0.22 & 0.12 & 0.31 & 0.29 & 0.06 & 0.39 & 0.21 & -0.16 & 0.19 & 0.31 & -0.05 & 0.02 & 0.26 & 0.13 & 0.07 & 0.26 & 0.19 & -0.09\end{array}$ $\begin{array}{lllllllllllllllllll}\text { Q51 } & -0.14 & 0.04 & 0.11 & 0.09 & 0.22 & 0.26 & 0.25 & -0.24 & 0.02 & 0.00 & -0.22 & -0.04 & 0.11 & 0.30 & 0.35 & 0.15 & 0.29 & 0.06\end{array}$

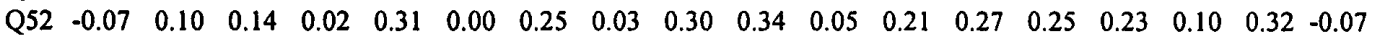
$\begin{array}{lllllllllllllllllll}\text { Q53 } & 0.36 & 0.06 & -0.14 & -0.23 & -0.12 & -0.09 & -0.32 & 0.28 & 0.01 & -0.07 & 0.25 & -0.10 & -0.30 & -0.27 & -0.18 & -0.17 & -0.16 & 0.19\end{array}$ $\begin{array}{lllllllllllllllllll}\text { Q54 } & -0.18 & 0.07 & 0.28 & 0.20 & 0.01 & 0.26 & 0.20 & -0.14 & 0.08 & 0.07 & 0.05 & -0.08 & 0.32 & 0.12 & 0.09 & 0.14 & 0.19 & -0.09\end{array}$ $\begin{array}{lllllllllllllllllll}\text { Q55 } & 0.73 & 0.02 & -0.31 & -0.21 & -0.05 & -0.23 & -0.35 & 0.37 & -0.03 & 0.09 & 0.51 & 0.09 & -0.33 & -0.35 & -0.08 & -0.23 & -0.18 & 0.03\end{array}$ $\begin{array}{lllllllllllllllllll}\text { Q56 } & 0.24 & 0.00 & -0.19 & -0.17 & -0.15 & -0.16 & -0.24 & 0.28 & 0.10 & 0.05 & 0.28 & -0.07 & -0.32 & -0.11 & -0.03 & -0.19 & -0.19 & 0.00\end{array}$ $\begin{array}{lllllllllllllllllll}\text { Q57 } & -0.03 & 0.14 & 0.18 & 0.11 & 0.00 & 0.13 & -0.06 & 0.02 & 0.12 & 0.28 & 0.00 & -0.02 & 0.15 & 0.08 & 0.10 & 0.22 & -0.02 & -0.04\end{array}$ $\begin{array}{lllllllllllllllllll}\text { Q58 } & -0.16 & 0.04 & 0.03 & 0.02 & 0.27 & 0.11 & 0.30 & -0.20 & 0.15 & 0.05 & -0.08 & 0.06 & 0.27 & 0.48 & 0.48 & 0.12 & 0.37 & -0.03\end{array}$ Q59 $\begin{array}{lllllllllllllllllll}0.12 & 0.06 & 0.04 & 0.21 & 0.07 & -0.09 & 0.25 & 0.03 & 0.28 & 0.08 & 0.17 & -0.09 & 0.03 & 0.13 & 0.29 & -0.05 & 0.25 & 0.13\end{array}$ $\begin{array}{lllllllllllllllllll}\text { Q60 } & 0.23 & -0.23 & -0.05 & -0.01 & -0.17 & -0.24 & -0.22 & 0.38 & 0.01 & -0.03 & 0.25 & -0.06 & -0.30 & -0.14 & 0.06 & -0.18 & -0.03 & -0.02\end{array}$ $\begin{array}{lllllllllllllllllll}\text { Q61 } & 0.07 & 0.20 & 0.14 & -0.05 & 0.25 & -0.08 & 0.16 & 0.11 & 0.14 & 0.28 & 0.01 & 0.19 & 0.24 & 0.22 & 0.19 & -0.14 & 0.20 & -0.04\end{array}$

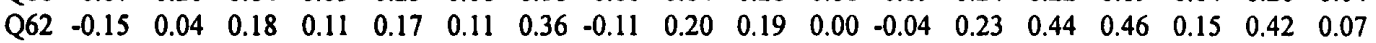
$\begin{array}{lllllllllllllllllll}\text { Q63 } & -0.13 & 0.11 & 0.17 & 0.27 & 0.24 & 0.12 & 0.48 & -0.14 & 0.40 & 0.18 & -0.05 & 0.08 & 0.23 & 0.24 & 0.26 & 0.09 & 0.39 & -0.04\end{array}$

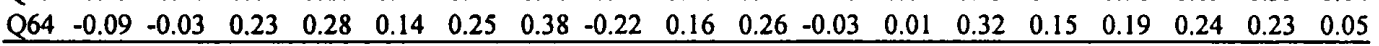

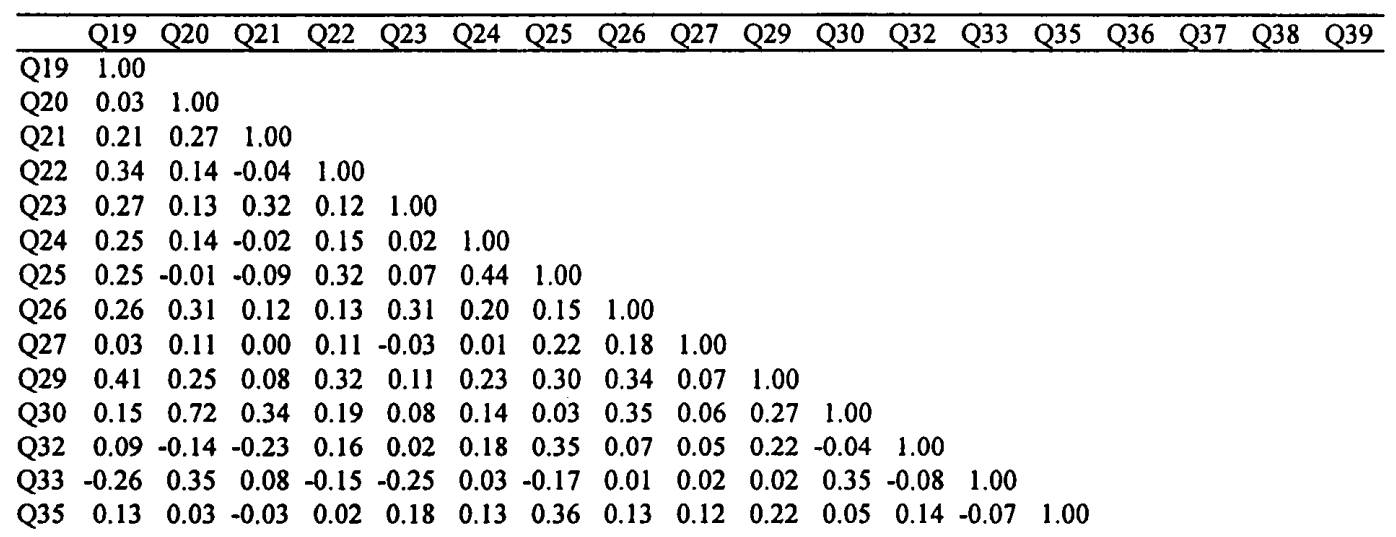




\begin{tabular}{|c|c|c|c|c|c|c|c|c|c|c|c|c|c|c|c|c|c|c|}
\hline & 19 & 20 & Q21 & 22 & Q23 & 24 & 25 & 26 & 27 & Q29 & Q50 & Q52 & Q33 & Q35 & Q36 & Q37 & Q38 & \\
\hline 36 & 0.37 & -0.07 & -0.08 & 0.25 & 0.10 & 0.22 & 0.33 & 0.24 & -0.09 & 0.41 & -0.05 & 0.30 & -0.14 & 0.22 & 1.00 & & & \\
\hline 37 & -0.19 & 0.30 & 0.00 & 0.02 & 0.06 & & .04 & & 0.21 & 07 & & & & & -0.17 & 1.00 & & \\
\hline 38 & 0.14 & 0.18 & 0.01 & 0.14 & 0.00 & 0.18 & 0.04 & & -0. & & & & & & 0.14 & -0.19 & 1.0 & \\
\hline 39 & 0.08 & 0.57 & 0.25 & -0.01 & 0.02 & 0.0 & -0.06 & 0.23 & -0.07 & 0.22 & 0.5 & -0.09 & & & -0.07 & 0.12 & & \\
\hline 41 & 0.23 & 0.02 & -0.13 & 0.58 & -0.03 & 0.11 & 0.31 & 0.08 & 0.16 & 0.21 & 0.11 & 0.28 & 0.01 & 0.17 & 0.34 & 0.02 & & \\
\hline 42 & 0.16 & -0.12 & -0.07 & 0.15 & 0.09 & 0.00 & 0.01 & 0.08 & -0.11 & 0.04 & -0.07 & 0.07 & -0.17 & -0.03 & 0.15 & 0.09 & -0.0 & -0. \\
\hline 43 & -0.17 & 0.19 & 0.07 & -0.01 & -0.17 & 0.10 & -0.05 & -0.01 & 0.18 & 0.02 & 0.16 & -0.06 & 0.39 & 0.13 & -0.15 & 0.44 & -0.10 & 0.1 \\
\hline 44 & 0.19 & 0.05 & -0.08 & 0.34 & -0.07 & 0.29 & 0.29 & 0.09 & 0.17 & 0.25 & 0.01 & 0.36 & -0.09 & 0.04 & 0.32 & -0.03 & 0.22 & -0.13 \\
\hline 45 & 0.42 & 0.18 & 0.24 & 27 & 0.33 & 0.24 & 0.21 & 0.49 & -0.05 & 0.44 & 0.21 & 0.17 & -0.09 & 24 & 0.44 & 0.05 & 0.27 & 0. \\
\hline 46 & -0.22 & 0.09 & -0.04 & & -0.14 & -0.07 & -0.01 & 0.03 & 12 & 0.10 & 0.08 & 0.04 & 0.22 & 05 & -0.09 & 0.18 & -0.10 & \\
\hline 47 & 0.60 & 0.17 & 0.17 & & 0.22 & 0.25 & 0.36 & & 0.09 & 0.50 & 0.19 & 0.21 & -0.12 & 24 & 0.39 & 0.01 & 0.26 & \\
\hline 48 & 18 & 0.56 & 0.37 & & 0.11 & 0.09 & -0.03 & & & 0.27 & 0.57 & -0.06 & 16 & 06 & .04 & 0.13 & 0.08 & 0.8 \\
\hline 49 & 0.02 & 0.31 & 0.04 & & -0.03 & -0.03 & 0.07 & & & 0.08 & 0.36 & 0.00 & 41 & .06 & -0.10 & 0.16 & .21 & 0.33 \\
\hline 50 & 0.27 & .12 & -0.02 & & 0.00 & 0.22 & 0.31 & & & 0.19 & 0.06 & 0.33 & & 10 & 0.29 & .19 & 0.29 & -0.1 \\
\hline 51 & 0.17 & 0.02 & 0.19 & 0.12 & 0.42 & -0.06 & 0.06 & 0.18 & & 0.14 & -0.10 & 0.07 & & & 11 & 1.06 & 0.1 & -0.03 \\
\hline 52 & 0.20 & 0.08 & -0.02 & 0.25 & 0.07 & 0.31 & 0.30 & 0.28 & 0.18 & 0.23 & 0.05 & 0.25 & -0.01 & 16 & 0.33 & -0.02 & 0.42 & -0.0 \\
\hline 53 & -0.16 & 0.27 & -0.02 & -0.13 & -0.01 & 0.06 & -0.17 & -0.09 & 0.05 & -0.12 & 0.24 & -0.20 & 0.34 & 04 & -0.31 & 0.23 & -0.09 & 0.1 \\
\hline 54 & 0.23 & -0.06 & 0.09 & 0.26 & 0.20 & 0.05 & 0.16 & 0.09 & -0.02 & 0.02 & 0.07 & 0.14 & -0.16 & .15 & 0.15 & -0.40 & 0.24 & -0.06 \\
\hline 55 & -0.18 & 0.52 & 0.09 & 0.02 & -0.05 & 0.00 & -0.12 & 0.09 & 0.11 & 0.13 & 0.47 & -0.13 & 0.61 & 0.04 & -0.14 & 0.31 & -0.11 & 0.35 \\
\hline 56 & -0.16 & 0.08 & 0.03 & -0.01 & -0.14 & 0.02 & -0.02 & 0.07 & 0.20 & 0.06 & 0.12 & -0.01 & 0.32 & 0.06 & 0.00 & 0.27 & -0.09 & 0.01 \\
\hline 557 & 0.11 & 0.01 & -0.04 & 0.54 & 0.04 & 0.16 & 0.21 & 0.02 & 0.07 & 0.14 & 0.04 & 0.25 & -0.10 & 0.09 & 0.20 & 0.11 & 0.02 & -0.16 \\
\hline 58 & 0.37 & 0.11 & 0.16 & 0.25 & 0.44 & 0.07 & 0.29 & 0.35 & 0.13 & 0.36 & 0.02 & 0.19 & -0.41 & 0.20 & 0.26 & 0.00 & 0.18 & 0.11 \\
\hline 59 & 0.31 & 0.20 & 0.19 & 0.18 & 0.24 & 0.12 & 0.14 & 0.37 & 0.23 & 0.27 & 0.22 & 0.02 & 0.03 & 0.23 & 0.18 & 0.35 & 0.15 & 0.01 \\
\hline 60 & -0.06 & 0.26 & 0.10 & -0.05 & -0.11 & 0.15 & -0.11 & 0.06 & 0.21 & 0.09 & 0.23 & -0.10 & 0.28 & 0.04 & -0.14 & 0.36 & 0.03 & 0.15 \\
\hline 61 & 0.22 & 0.22 & -0.05 & 0.21 & 0.07 & 0.23 & 0.27 & 0.36 & 0.14 & 0.55 & 0.14 & 0.24 & 0.04 & 0.31 & 0.38 & 0.12 & 0.30 & 0.07 \\
\hline 62 & 0.28 & 0.12 & 0.17 & 0.22 & 0.30 & 0.12 & 0.26 & 0.43 & 0.16 & 0.33 & 0.17 & 0.26 & -0.28 & 0.14 & 0.20 & 0.06 & 0.39 & 0.09 \\
\hline 63 & 0.47 & 0.04 & 0.12 & 0.32 & 0.24 & 0.17 & 0.34 & 0.47 & 0.05 & 0.39 & 0.14 & 0.15 & -0.18 & 0.24 & 0.44 & 0.00 & 0.27 & 0.01 \\
\hline 54 & 0.38 & -0.04 & 0.01 & 0.28 & 0.06 & 0.07 & 0.11 & 0.16 & 0.05 & 0.17 & 0.15 & 0.20 & -0.15 & 0.13 & 0.23 & 0.01 & 0.03 & -0.14 \\
\hline
\end{tabular}

\begin{tabular}{llllllllllllllllll}
\hline Q41 & Q42 & Q43 & Q44 & Q45 & Q46 & Q47 & Q48 & Q49 & Q50 & Q51 & Q52 & Q53 & Q54 & Q55 & Q56 & Q57 & Q58 \\
\hline
\end{tabular}

Q41 1.00

Q42 $0.14 \quad 1.00$

Q43 $\quad-0.02 \quad 0.06 \quad 1.00$

$\begin{array}{lllll}\mathrm{Q} 44 & 0.25 & 0.13 & 0.01 & 1.00\end{array}$

$\begin{array}{llllll}\text { Q45 } & 0.25 & 0.24 & 0.06 & 0.27 & 1.00\end{array}$

$\begin{array}{llllllll}\text { Q46 } & 0.03 & -0.28 & 0.26 & -0.09 & 0.01 & 1.00\end{array}$

$\begin{array}{llllllll}\text { Q47 } & 0.39 & 0.23 & 0.01 & 0.31 & 0.65 & -0.11 & 1.00\end{array}$

$\begin{array}{lllllllll}\mathrm{Q} 48 & -0.08 & 0.05 & 0.25 & -0.08 & 0.24 & 0.12 & 0.18 & 1.00\end{array}$

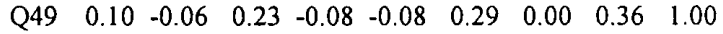

$\begin{array}{lllllllllll}\text { Q50 } & 0.34 & 0.04 & -0.09 & 0.29 & 0.28 & -0.10 & 0.32 & -0.10 & 0.00 & 1.00\end{array}$

$\begin{array}{lllllllllllll}\text { Q51 } & 0.10 & 0.16 & -0.09 & -0.05 & 0.30 & -0.01 & 0.18 & 0.06 & -0.18 & 0.06 & 1.00\end{array}$

$\begin{array}{lllllllllllll}\text { Q52 } & 0.22 & -0.02 & -0.02 & 0.29 & 0.37 & -0.03 & 0.35 & -0.01 & -0.06 & 0.24 & 0.01 & 1.00\end{array}$

$\begin{array}{llllllllllllll}\text { Q53 } & -0.07 & -0.10 & 0.22 & -0.26 & -0.15 & 0.27 & -0.17 & 0.12 & 0.29 & -0.07 & -0.07 & -0.22 & 1.00\end{array}$

$\begin{array}{lllllllllllllllll}\text { Q54 } & 0.24 & -0.07 & -0.11 & 0.02 & 0.27 & 0.04 & 0.29 & 0.02 & -0.05 & 0.37 & 0.24 & 0.19 & -0.07 & 1.00\end{array}$

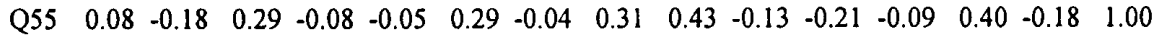

$\begin{array}{lllllllllllllllll}\mathrm{Q} 56 & -0.03 & -0.10 & 0.43 & 0.00 & 0.03 & 0.43 & -0.04 & 0.05 & 0.20 & -0.20 & -0.11 & 0.12 & 0.28 & -0.06 & 0.35 & 1.00\end{array}$

$\begin{array}{llllllllllllllllll}\text { Q57 } & 0.25 & 0.05 & 0.15 & 0.39 & 0.28 & -0.06 & 0.28 & -0.03 & 0.01 & 0.27 & 0.09 & 0.13 & -0.10 & 0.19 & -0.01 & 0.12 & 1.00\end{array}$

$\begin{array}{llllllllllllllllllll}\text { Q58 } & 0.13 & 0.29 & -0.11 & 0.10 & 0.47 & -0.06 & 0.40 & 0.19 & -0.09 & 0.13 & 0.63 & 0.24 & -0.19 & 0.21 & -0.27 & -0.05 & 0.12 & 1.00\end{array}$ Q59 $\begin{array}{llllllllllllllllllll} & 0.25 & 0.10 & 0.13 & 0.17 & 0.51 & 0.11 & 0.49 & 0.16 & 0.02 & 0.05 & 0.24 & 0.19 & -0.03 & 0.12 & 0.05 & 0.12 & 0.16 & 0.26\end{array}$ $\begin{array}{lllllllllllllllllll}\text { Q60 } & -0.06 & 0.04 & 0.70 & 0.01 & 0.13 & 0.32 & 0.13 & 0.25 & 0.14 & -0.17 & -0.04 & -0.02 & 0.30 & -0.03 & 0.29 & 0.42 & 0.09 & 0.02\end{array}$ $\begin{array}{lllllllllllllllllll}\text { Q61 } & 0.32 & -0.02 & -0.01 & 0.17 & 0.39 & 0.09 & 0.49 & 0.12 & 0.02 & 0.30 & 0.03 & 0.42 & -0.11 & 0.10 & 0.02 & 0.05 & 0.11 & 0.26\end{array}$ $\begin{array}{lllllllllllllllllll}\text { Q62 } & 0.16 & 0.13 & -0.06 & 0.23 & 0.38 & -0.04 & 0.34 & 0.16 & -0.07 & 0.17 & 0.41 & 0.32 & -0.18 & 0.14 & -0.19 & -0.04 & 0.02 & 0.56\end{array}$ $\begin{array}{lllllllllllllllllll}\mathrm{Q} 63 & 0.37 & 0.14 & -0.13 & 0.26 & 0.55 & 0.01 & 0.59 & 0.09 & -0.10 & 0.28 & 0.32 & 0.39 & -0.25 & 0.21 & -0.16 & -0.15 & 0.06 & 0.33\end{array}$ \begin{tabular}{lllllllllllllllllll}
$\mathrm{Q} 64$ & 0.36 & 0.15 & -0.16 & 0.17 & 0.28 & -0.20 & 0.38 & -0.04 & -0.12 & 0.25 & 0.20 & 0.07 & -0.23 & 0.21 & -0.21 & -0.23 & 0.18 & 0.14 \\
\hline
\end{tabular}

\begin{tabular}{lcccccc}
\hline & Q59 & Q60 & Q61 & Q62 & Q63 & Q64 \\
\hline Q59 & 1.00 & & & & & \\
Q60 & 0.29 & 1.00 & & & & \\
Q61 & 0.35 & 0.05 & 1.00 & & & \\
Q62 & 0.33 & 0.07 & 0.22 & 1.00 & & \\
Q63 & 0.56 & -0.03 & 0.42 & 0.44 & 1.00 & \\
Q64 & 0.29 & -0.12 & 0.21 & 0.23 & 0.41 & 1.00 \\
\hline
\end{tabular}

